The Gas Council's London Research Station :

Mr. G. U. Hopton

Mr. G. U. Hopton has been appointed the new director of the Gas Council's London Research Station at the Fulham Laboratories. Ho was senior research chemist of the North Thames Gas Board from 1952, until the rotirement of Dr. R. H. Griffith last August, when he became acting director. Mr. Hopton gained a first-class honours degree in chemistry at Oxford and the same year joined the Gas Light and Coke Company. In 1936 he was awarded the MacNab Medal of the Institution of Chemical Engineers and in 1945 gained the H. E. Jones Medal of the Institution of Gas Engineers. From 1950 until this year he was chairman of the board of examiners of the Institution of Chemical Engineers. Mr. Hopton has also been vice-president of the Institution. $\mathrm{He}$ is a member of the board of studies in engineering of the National Council for Technological Awards.

British Museum (Natural History) : Appointments

The Principal Trustees of the British Museum have appointed Dr. F. C. Fraser, keeper of zoology, and Mr. J. E. Dandy, keeper of botany, to be deputy chief scientific officers in the British Museum (Natural History). They have also appointed Mr. J. P. Doncastor to be keeper of the Department of Entomology in the British Museum (Natural History), in succession to Dr. W. E. China, who will retire on January 31 ; and Dr. J. P. Harding and Mr. J. F. Porkins to be deputy keopers in the Departments of Zoology and Entomology, respectively.

Mr. Doncaster, who has been a deputy kooper in the Department of Entomology since December 1955, was educated at Leighton Park School, Reading, and St. Catharine's College, Cambridge. After some years on entomological work at the Plant Virus Research Station, Cambridge, he entered the British Museum (Natural History) in 1937, to take charge of the newly formed Exhibition Section. During the War he was seconded to the Agricultural Research Council to work on the aphid vectors of potato viruses, returning to the Museum in 1945 to begin the re-designing and reconstruction of war-damaged exhibits. In 1951 he joined the staff of the Department of Entomology to take charge of the collections of Homoptera (Sternorhyncha) and Thysanoptera, and to reorganize the collections of Aphididae. His published works have dealt mainly with the systematics of aphids and their role as virus vectors.

Dr. Harding was educated at Torquay Grammar school, University College, Exeter, the University of Cincinnati, and King's College, Cambridge. Prior to joining the staff of the British Museum (Natural History) in 1937, Dr. Harding worked for a year as assistant naturalist in the Ministry of Agriculture and Fisheries. Dr. Harding is a carcinologist specializing in the Entomostraca, on which he has published many papers in journals of learned societies.

Mr. Perkins was educated at Newton College and the Imperial College of Science and Technology (Royal College of Science), London, graduating in 1932 and being awarded the Forbes Medal. He entered the British Museum (Natural History) in 1933, where he has worked on the parasitic Hymenoptera, and in particular Ichneumonidae. During the War he was seconded to the Ministry of Agriculture, where he was associated with some of the early trials of D.D.T. against crop pests. His publishod works have been concerned with the general classification of the Ichneumonidae, and revisions of groups of this family particularly in relation to the British fauna.

\section{Exhibition of The Institute of Physics and The Physical Society}

If one function of science is to enable us to rationalize our sense perceptions, we need instruments and apparatus to help us perceive; the coincidence of the pointer and scale is of profound importance. As our scientific knowledge ramifies and incroases in complexity, demands upon apparatus for precise measurement and manipulation become more exacting. The manner in which this demand has been met so far will be clearly demonstrated at the annual exhibition to be held by The Institute of Physies and The Physical Society at The Royal Horticultural Society's Halls, Westminster, London, S.W.1, from January 16 until 1 p.m. on January 20 . Lectures will be given by : Mr. F. S. Burt (Admiralty Research Laboratory) on "Hydrodynamics Research", on January 17 ; Dr. G. E. R. Deacon (National Institute of Oceanography) on "The Physics of the Ocean", on January 18 ; and Dr. F.P. Bowden (Laboratory for the Physics and Chemistry of Solids, Cambridge) on "Some Physical Problems in Travelling at Supersonic Speed", on January 19. These lectures will bo at $5.45 \mathrm{p} . \mathrm{m}$. The prize-giving of the Craftsmanship Competition will take place in the lecture theatre on January 19 at 3 p.m. The Society has published a Handbook of Scientific Instruments and Apparatus (price 6s., plus $2 s$. postage), which is a guide to the exhibits. It is also a reference book on recent developments in the design of physical apparatus; it provides a list of manufacturers and of recent scientific books. As a means of planning one's visit to the Exhibition, the handbook seems indispensable. Further information can be obtained from The Institute of Physics and The Physical Society, 47 Belgrave Square, London, S.W.1.

\section{Institute of Information Scientists}

A Fulx syllabus for education in information work has now been prepared by the Institute of Information Scientists ; it has also been approved by Aslib. Courses on "Collecting and Communicating Scientific Information" based on this syllabus have been arranged at the Northampton College of Advanced Technology, St. John Street, London, E.C.1, to start on January 24, and will comprise evening classes twice a week during two years. The Institute will hold (external) examinations, based on the syllabus, for the Certificate of the Institute, and will be set in two groups, at the end of 1961 and 1962, respectively. Details of the course may be obtained from the College, and other information from the honorary socretary of the Institute, J. Farradane, "Torran", Crofton Road, Orpington, Kent.

\section{Forest Research and Training Institute for Latin America}

A Focus for forest research and training in Latin America has been acquired with the permanent establishment-following four years on a temporary basis-of the Latin American Forestry Institute for Research and Training at the Forestry School of the University of Los Andes, Merida, Venezuela. A multilateral agreement has been reached between the Food and Agriculture Organization, under the aus- 